\title{
Real estate development analysis in China
}

Real estate

\author{
Ling Hin Li
}

Department of Surveying, University of Hong Kong, Hong Kong

\section{Introduction}

When a new land market is being developed, a common issue that normally emerges is the measurement of asset values for investment purposes. In the privatization process of most socialist economies, verifying asset values is especially important as the state enterprises usually own a substantial proportion of real assets in the country. In China, owing to the practice of administrative allocation of land assets before the land use rights reforms (Walker and Li, 1994), the understanding of the problems in the appraisal of investment values for either the real estate assets themselves or the enterprises which own these assets is essential. In this paper, an attempt is made to explain the common practice of establishing the asset values in China by valuers and financial consultants in Hong Kong and the problems most real estate investors will face when carrying out investment analysis for real estate development in this market. A case study of a joint venture development between a developer from Hong Kong and a Chinese partner is examined and the issues involved in the development analysis are discussed.

\section{J oint venture projects in China}

Figure 1 explains the normal stages involved in a joint venture real estate development project in China. For the Chinese partner, the first stage is to apply for the transfer of administratively-allocated land to market land (Walker and $\mathrm{Li}, 1994)$. This stage involves primarily the assessment of the value of land to be used as capital share of the Chinese partner.

In 1994, a joint policy document by the Ministry of Finance, the M inistry of Construction, the State Land Administration Bureau and the National A dministrative Bureau of State-owned Property entitled "Regulations on the appraisal of land value in the audit of state assets" (Wang and Wang, 1995) was announced. The main purpose of these regulations is to set the baseline land prices for land assets that belong to the state enterprises after a general audit of the property rights, areas and boundaries of these assets has been carried out. State enterprises include those using their land asset as capital share in the joint venture activities and those changing into share-capital mode. Similar regulations are also set out for appraising assets bought by foreign investors under the Administration Procedures of the A ppraisal of Assets Invested by Foreign Investors (1994) (referred to as the 1994 Procedures hereafter). Part three of the 1994 Procedures lists the methods of appraisal: 
Journal of

Property

Finance

7,4

44

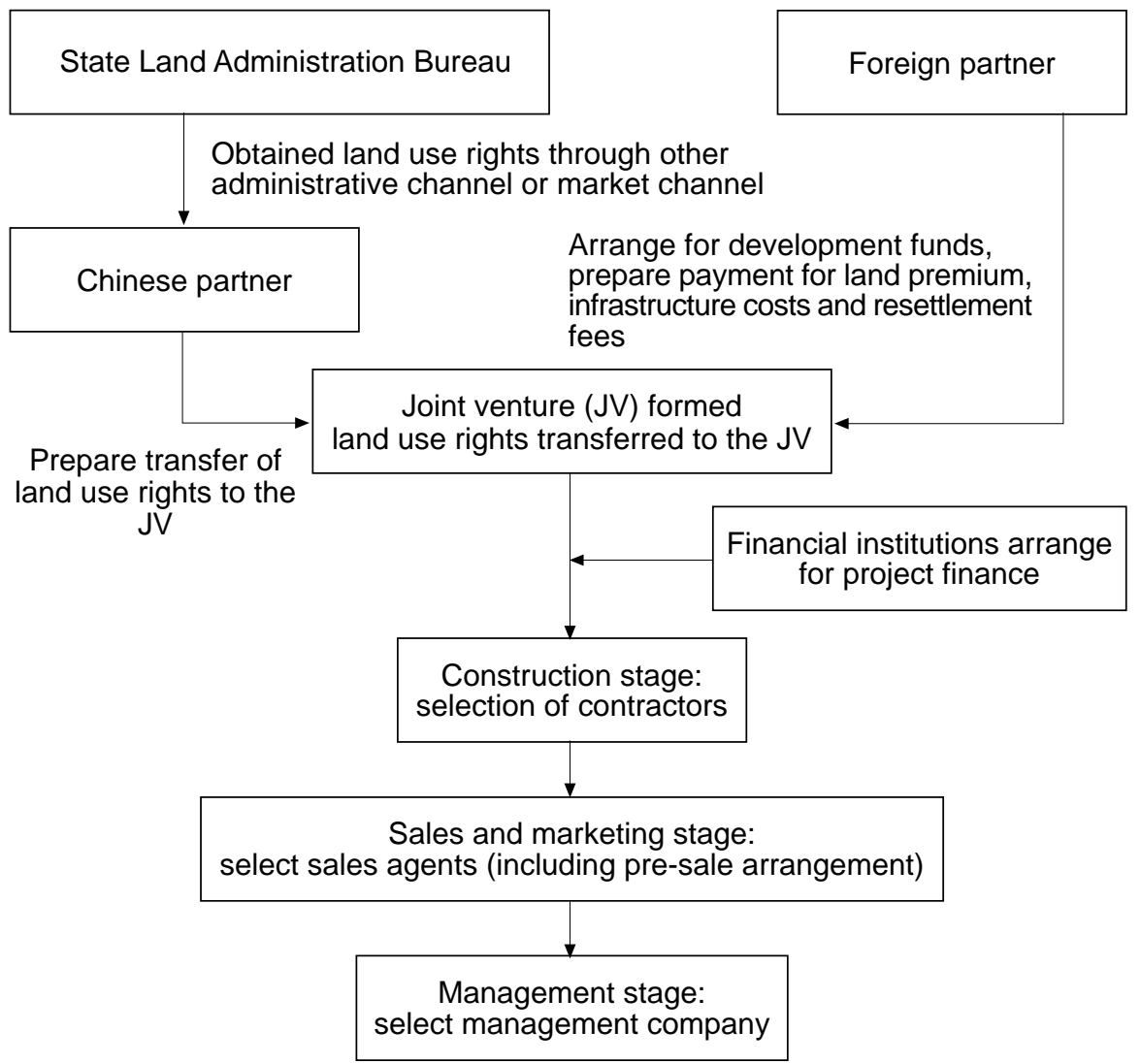

(1) A rticle 10. The appraisal of foreign investment assets must be conducted in accordance with the appraisal methods and relevant provisions set forth in these Procedures and on the basis of the current state, degree of wear, indications of performance, technical parameters, replacement cost, profitability, etc. of the assets.

(2) A rticle 11. The methods of appraising foreign investment assets shall include on-site inspection, technical test and value appraisal, of which value appraisal shall include:

- the market-based method;

- the cost-based method;

- the profit-based method; and

- other methods prescribed by the Ministry of Finance or the State A dministration for Commodity Inspection.

(3) A rticle 12. Where the market-based method is used to appraise the value of foreign investment assets, reference shall be made to the current market price of identical or similar assets. 
(4) Article 13. Where the cost-based method is used to appraise the value of foreign investment assets, the reestimated value shall be determined on the basis of replacement cost of the assets being appraised as brand-new assets less the cumulative depreciation calculated on the basis of the replacement cost with respect to factors such as changes in productivity, degree of newness, etc. A Iter natively, the reestimated value of the assets may be obtained by determining their degree of newness on the basis of the current state and useful life of the assets being appraised with regard

Real estate development in China to factors such as changes in function, etc.

(5) Article 14. Where the profit-based method is used to appraise the value of foreign investment assets, the current value of the assets being appraised shall be calculated on the basis of the reasonably expected profitability of such assets at a suitable discount rate.

(6) A rticle 15. The appraisal of foreign investment assets shall be conducted in accordance with the following procedures:

- the applicant files an application for appraisal;

- the appraisal authorities accept the application following preliminary examination of information;

- appraisal personnel draft an appraisal plan;

- receipts, certificates and information provided by the applicant are examined and verified and market surveys are conducted inside and outside China;

- an on-site inspection is conducted;

- a suitable appraisal method is selected for the appraisal; and

- a Certificate of A ppraisal is issued.

(7) Article 16. A pplicants applying for the appraisal of foreign investment assets shall fill out an application form, clearly stating the purpose and objects of and requirements for appraisal, and shall also provide information such as a list of property items, Customs declaration list, contract, receipts, insurance policy, a list of maintenance expenses, technical documentation concerning equipment, etc.

In addition, according to Regulation 7 of the 1994 Regulations on the A ppraisal of Land Value in the Audit of State A ssets, those local authorities which have compiled their benchmark land prices $(\mathrm{Li}, 1995)$ and any other adjustment can base their appraisals of land values on the published benchmark prices in accordance with the Interim Regulations of the People's Republic of China on Granting and Transferring the Rights to the Use of State-owned Land in Cities and Towns (1991) and the Provisional Procedures for the A dministration of A ppraisal Practice in the U rban Real Estate Market (1992). Theoretically therefore, local government as well as developers should have a common reference point when assessing development potential of various urban sites.

Under Regulation 10 of the same document, it is stated that the valuation methods used in the asset valuation are recommended to be one of the following: 
Journal of

Property

Finance

7,4

46

market comparison; investment method and cost approach. In addition, Regulation 13 requires the state enterprises to form an asset valuation committee to oversee the valuation work which should take into account the following data:

- Historical background of the ownership and use of the land.

- Site map with boundary, land registration document etc.

- Locational advantages and quality of the land.

- Benchmark prices and other adjustment in the locality.

- Data on the local property market.

- Other relevant factors that will affect the asset values of the enterprises.

In real life, however, the system may not work as smoothly as expected. The following development analysis will try to explain this.

\section{J oint venture - case study}

In this analysis, we examine a joint venture project in Beijing, the capital city of China, and compare the ways the market views development value of land and the benchmark land price set by the government in negotiating with foreign investors. The project started in August 1993 and is located in the Chaoyang district on the south-east fringe of the city. The details of the site are as follows:

- $\quad$ Site area: 37,233sq.m.

- Use: commercial (25 per cent)/residential (75 per cent) mixed development.

- Building height: not exceeding 99.6m.

- Plot ratio: not exceeding 5.99.

- Length of land use rights: 70 years for residential and 40 years for commercial.

The site in this case study is ranked as grade four land in the Chaoyang District, and according to the Beijing 1993 benchmark land price table (BMP table) (see Table AI in the A ppendix), benchmark land price for this particular site in Beijing city should lie between the lower end figures and the upper end figures, therefore:

US $\$ 180 \times 4.2+[U S \$ 68+U S \$ 20] \times 5.99+$ US $\$ 740 \times 2+$ US $\$ 20$ $=$ US $\$ 2,783.12 / \mathrm{sq} \cdot \mathrm{m}$.

This represents the lower end figures of the BMP table for grade four land for apartment use. The term is chosen because in China, mixed office and residential building is normally classed as apartment building. Hence, the lower end benchmark land price for this site is estimated to be:

US $\$ 2,783.12 \times 37,233 s q . m=$ US $\$ 103.6$ million (or 880 million Yuan at the exchange rate of US $\$ 1=8.5$ Yuan).

If on the other hand the site represents prime location in this neighbourhood, the average land price should become: 
US\$230 $\times 4.2+[U S \$ 100+U S \$ 50] \times 5.99+U S \$ 980 \times 2+U S \$ 56$

$=$ US $\$ 3,880.5 / \mathrm{sq} \cdot \mathrm{m}$.

This represents the upper end figures of the BMP table for grade four land for apartment use. Hence, the upper end benchmark land price for this site is estimated to be:

US $\$ 3,880.5 \times 37,233$ sq. $m=$ US\$144.5 million (or 1,228 million Yuan).

However, when we examine the professional valuation report (which was dated as at A pril 1995) for the foreign partner of this project, the transfer fee of the land, which is the agreed land price for the particular site to be paid to the local government, amounts to US $\$ 16.8$ million (or 142 million Yuan) only. This sum is substantially smaller than the official benchmark land price.

If T ableA I represents benchmark land prices in Beijing in 1993 only, then we should envisage much higher figures for the BM P table for 1995 given the strong expected demand in the property market in Beijing between 1993-1996 (Lin, 1994). If this is the case, there is no way a developer can carry out development analysis based on the guideline land prices compiled by the government.

This case however is not an isolated one. We can observe the divergence between market development analysis of real estate projects and the official benchmark land prices from other market activities in Beijing city.

We can observe from Tablel that market land prices fall below the level of the official benchmark land prices in the major urban districts in Beijing. For instance, lot 1 in the above table is an average site of grade one land (Wangfujing Street is the main shopping and business street in Beijing) for commercial use. It has a plot ratio of 8.4 where the existing tenant is assumed to be a state enterprise. The average base land price of this site should be in the region between:

US $\$ 400 \times 6.3+[$ US $\$ 68+$ US $\$ 20] \times 8.4+$ US\$740 $\times 2=$ US $\$ 4,739.2 /$ sq.m

(low end figures in the BMP table) to:

US\$680 $\times 6.3+[\mathrm{US} \$ 100+\mathrm{US} \$ 50] \times 8.4+\mathrm{US} \$ 980 \times 2=\mathrm{US} \$ 7,504.4 / \mathrm{sq} \cdot \mathrm{m}$. (upper-end figures in the table).

However, the actual market transaction price is : US\$3,716.5/sq.m, which is 22 per cent below the minimum BMP and 50 per cent lower than the maximum figures in the BMP table.

In the other example, we can look at the last transaction in Table I which is also a Chaoyang District development. A ccording to the benchmark land prices in Table A I, the land price should fall between:

US $\$ 400 \times 4.2+[U S \$ 68+U S \$ 20] \times 5.12+U S \$ 740 \times 2=U S \$ 3,611 / \mathrm{sq} . \mathrm{m}$. (lower end figures in the BMP table) to:

US $\$ 680 \times 4.2+[U S \$ 100+U S \$ 50] \times 5.12+$ US $\$ 980 \times 2=U S \$ 5,584 / s q . m$. (upper end figures in the BMP table).

A gain, the actual market transaction price for this site is only US $\$ 903 /$ sq.m.
Real estate development in China 


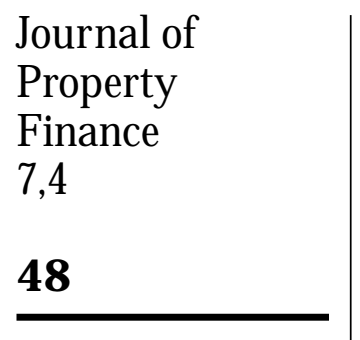

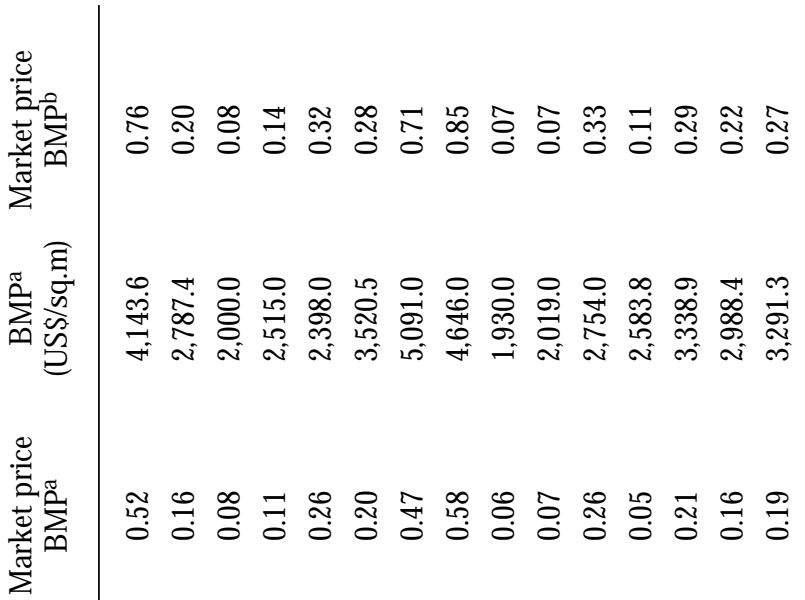

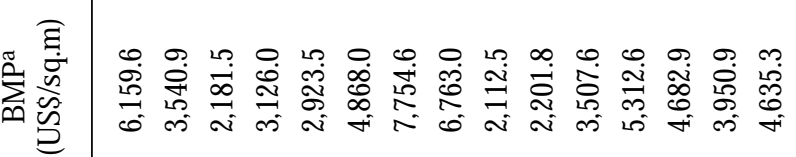

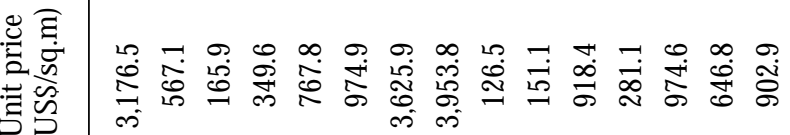

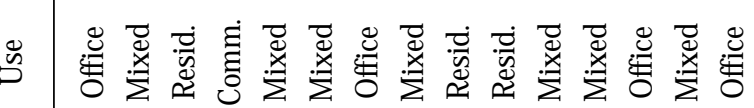

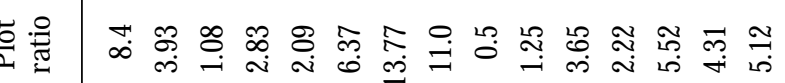

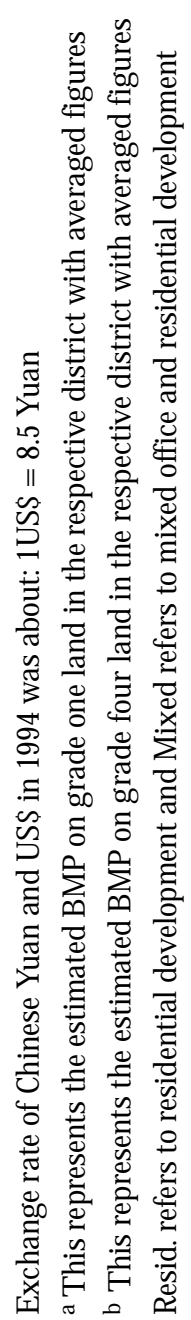

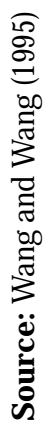

Table I. land sale records and BMP in Beijing in 1994

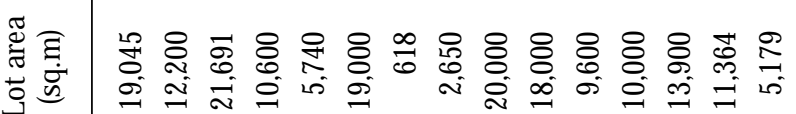

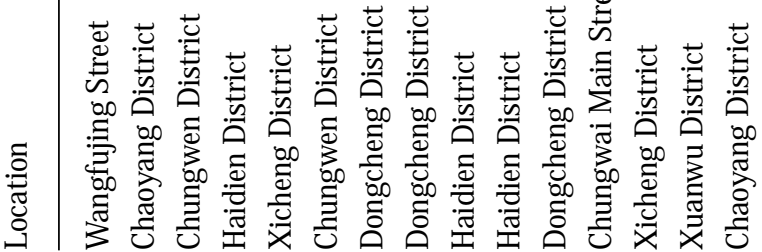


There is however one way of explaining this. When we look back to Figure 1, we may notice that while the Chinese partner is preparing the transfer of land from administratively-allocated land to market land, the foreign partner should prepare for the development funds which include the payment of land premium and the other fees such as infrastructure and resettlement. Here, we can divide the financial burden of a developer into two major parts, namely the land premium and the preparation fees. Table AI in the A ppendix shows that the last three columns (or the land development fees) give a fixed sum to each plot of land irrespective of the development characteristics of the land. To this extent, it distorts the residual nature of land value. Hence, when we turn back to Table I, we may re-apply only the first section of the official benchmark land price formula (i.e. BM P/sq.m = (1) $\times$ plot ratio factor $+[(2)+(3)] \times$ plot ratio) to the compilation of benchmark land prices and they are shown in Table ll.

From Table II, we begin to see a relatively logical function of the BMPs. In the ratios between the actual market land prices and the corresponding BM Ps, it shows that in most cases BM Ps can serve as a reference point for both the developer and the local authority. This is especially obvious in grade four land where BM Ps can serve as the minimal land price, or where the upset price in an ordinary auction case and final market price actually exceed the BM P.

For any new player in this market, the only piece of official information on market land price is the BM P table. This is supposed to be the reference information for both the local authority, who has power to sell land use rights, and the developer to negotiate in the transitional period of the setting up of a real market mechanism. How ever, the benchmark land price as appraised by the authority is composed of several elements such as the conveyance fee of the land use rights (i.e. the first component of the Beijing BM P formula), payment for infrastructure development in the neighbourhood and the compensation payment for sitting tenants. This is conceptually different from what developers from market economies would normally perceive land price to be. Developers and investors will therefore have to be more critical in utilizing this official information.

For a proper development analysis to be carried out in this market, foreign developers have to be very careful in interpreting information. Here, we will utilize the information available in the market as well as the official benchmark land price table to try to analyse and re-structure the development potentials of the project in the case study:

- Land cost: US\$75/sq.m of floor area or accommodation value[1].

- Construction cost: US\$210/sq.m (see [2] and Tables AIII and A IV of the A ppendix).

- Preparation fees: US\$486.5/sq.m of floor area[3].

- Total cost: US\$771.5/sq.m of floor area.

- Selling price: US\$210/sq.m of floor area[4]. 


\begin{tabular}{l|} 
Journal of \\
Property \\
Finance \\
7,4 \\
$\mathbf{5 0}$ \\
\hline
\end{tabular}

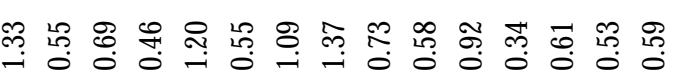

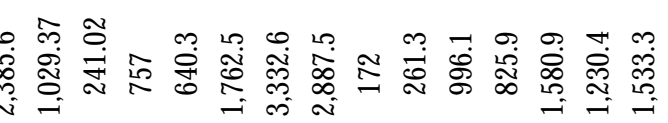

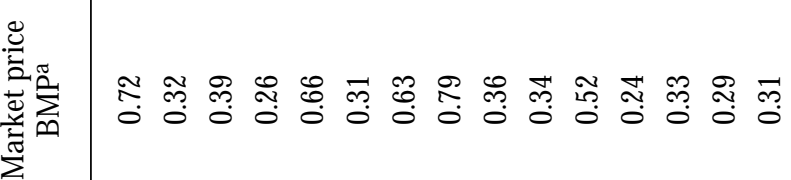

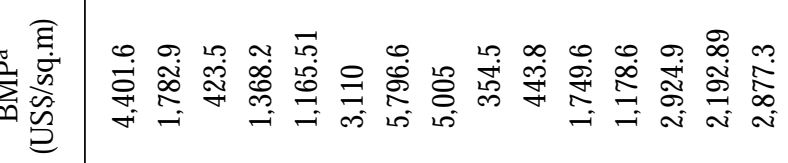

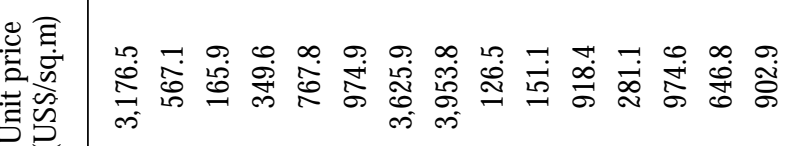

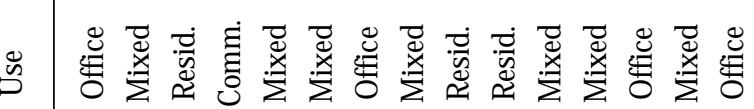

흠

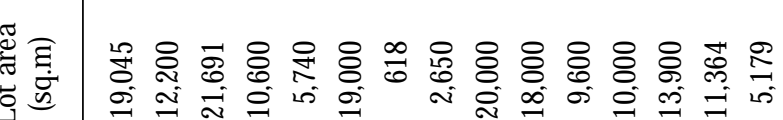

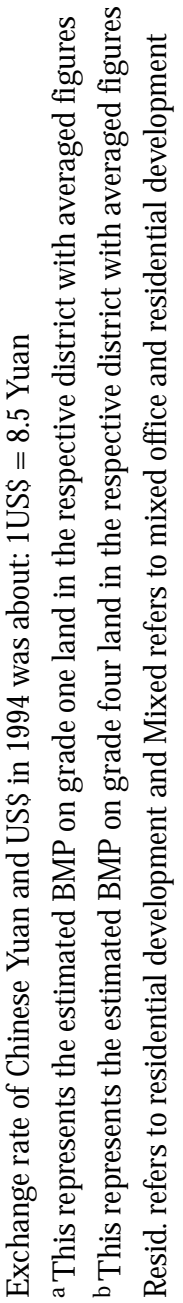

Table II.

Comparison of market land prices and re-compiled BMP in Beijing in 1994

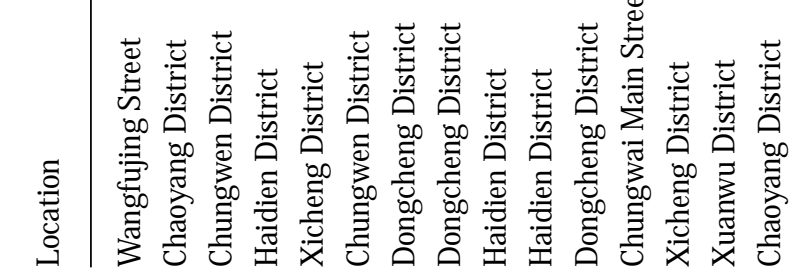

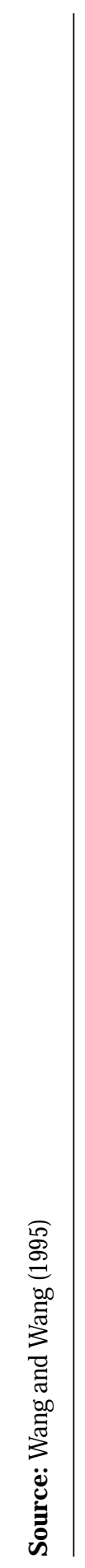


From this simple analysis, we find that the total development cost (i.e. land costs plus construction costs plus preparation fees) is about 772 Yuan/sq.m of gross area. This sum when converted into unit cost of the site area is about 4,624 Y uan/sq.m of the site area. This figure falls between the range of the BM P (3,611-5,584 Yuan) for this site estimated above. Consequently, the official BM P table does provide useful information for developer, but not what the table itself implies. By looking at the BMP table in this case study, it enables the developer to have a clearer understanding of the total costs, rather than just the land cost which the table implies, that he is going to face. By analysing the estimated development costs from the BMP table, financial feasibility of the project can then be deduced.

\section{Conclusion}

We have seen from the case study above that a major problem in carrying out development analysis for real estate development projects in China is the analysis of market and official information. This mainly emerges from the different interpretation of "value" under the socialist economy ( $\mathrm{L}, \mathrm{1}$ 1996). The references given by the state could be misleading if care is not given to countercheck the possible double-counting of various costs.

This is also one of the major reasons why the Hong Kong Stock Exchange (HKSE) has issued a further set of guidelines to the surveyors in Hong Kong when they are valuing land assets in China for the purposes of listing in the HK SE (Chau and Lai, 1995). But this set of guidelines is only good for asset valuation practice in China when the enterprises are going to be listed in the HKSE.

In a new and emerging market, information is always important to developers. However, since the market has yet to operate efficiently, official information is the only source of organized information in the market. This type of information is only useful and meaningful if and only if care is taken to re-structure the content so that the real implications of the information can be revealed. Reading between the lines is vital to developers at the initial stage of the feasibility study so that the full potential and pitfalls of the project can be identified.

\section{Notes}

1. L and cost is calculated by dividing the conveyance fee of US\$16,803,840 paid to the State Land A dministration Bureau of Beijing City by the total floor area (i.e. site area 37,233sq.m multiplied by the plot ratio of 5.99).

2. As this is a mixed development, the average construction cost for residential projects for local residents (relatively average construction standard) of US\$118/sq.m and the average cost for office development of US\$307/sq.m are given together. A ssuming this project is of a higher standard, an estimated cost of US\$177/sq.m (or 50 per cent higher than local housing construction cost) for residential project is made. Given the ratio of floor area between residential and commercial is 75:25, the average construction cost of US $\$ 210 / \mathrm{sq} . \mathrm{m}$ is assumed here for the whole development.
Real estate development in China 
Journal of

Property

Finance

7,4

52

3. Preparation fees include all the infrastructure and resettlement fees, i.e. listed items $2,3,4$, 5 in the A ppendix.

4. This is the average price of properties in the mixed development for sale on the open market in the Chaoyang District.

\section{References and further reading}

Beijing City Government Document (1993), No. 34.

Brueggeman, W.B. and Fisher, J.D. (1993), Real Estate Finance and Investments, Irwin, Boston, MA.

Cadman, D. and A ustin-Crowe, L. (1991), Property Development, Routledge, London.

Chau, K.W. and Lai, L.W.C. (1995), "Valuation of real estate assets in China", Journal of Valuation \& Investment, Vol. 13 No. 5, pp. 50-66.

Li, L.H. (1995), "T he official land value appraisal system under the land use rights reforms in China", T he A ppraisal Journal , Vol. LXIII No. 1, January.

Li, L.H. (1996), Privatization of Urban Land in Shanghai, Hong Kong University Press, Hong Kong (forthcoming).

Lin, Y. (Ed.) (1994), Beijing Property Report, China Foreign Real Estate Information Centre, Beijing (in Chinese).

Walker, A . and Li, L.H. (1994), "Land use rights reform and the real estate market in China", Journal of Real Estate Literature, Vol. 2 No. 2, July, pp. 199-211.

Wang, X.J. and Wang, G.X. (1995), Estate Price of China, China Product Price Publishing, B eijing.

\section{A ppendix. B eijing land and property prices}

With reference to Table A I:

(1) is the different land uses such as commercial, apartment, residential and industrial;

(2) is the fee charged for urban services and the connection of public utilities e.g. gas, etc.;

(3) is the fee charged for neighbourhood infrastructure;

(4) is the resettlement fee in urban areas;

(5) is the resettlement fee in urban fringe areas;

(6) is the resettlement fee in rural areas.

\begin{tabular}{|c|c|c|c|c|c|c|c|c|c|}
\hline \multirow{2}{*}{$\begin{array}{l}\text { Land } \\
\text { grade }\end{array}$} & \multirow[b]{2}{*}{ Com(1) } & \multicolumn{2}{|c|}{ Conveyance fee } & \multirow[b]{2}{*}{$\operatorname{lnd}(1)$} & \multicolumn{2}{|c|}{ Infrastructure fee } & \multicolumn{3}{|c|}{ Land development fee } \\
\hline & & $\operatorname{Apt}(1)$ & $\operatorname{Res}(1)$ & & (2) & (3) & (4) & (5) & (6) \\
\hline One & $400-680$ & $380-580$ & $250-340$ & $40-70$ & $68-100$ & $20-50$ & $740-980$ & $20-56$ & \\
\hline Two & $300-400$ & $280-380$ & $200-250$ & $30-40$ & $68-100$ & $20-50$ & $740-980$ & $20-56$ & \\
\hline Three & $250-300$ & $230-280$ & $125-200$ & $25-30$ & $68-100$ & $20-50$ & $740-980$ & $20-56$ & \\
\hline Four & $190-250$ & $180-230$ & $100-125$ & $20-25$ & $68-100$ & $20-50$ & $740-980$ & $20-56$ & \\
\hline Five & $125-190$ & $125-180$ & $75-100$ & $15-20$ & $68-100$ & $20-50$ & $740-980$ & $20-56$ & \\
\hline Six & $65-125$ & $65-125$ & $50-75$ & $10-15$ & $68-100$ & $20-50$ & $740-980$ & $20-56$ & $10-23$ \\
\hline Seven & $50-65$ & $40-65$ & $20-50$ & $5-10$ & $68-100$ & $20-50$ & $740-980$ & $20-56$ & $10-23$ \\
\hline Eight & $10-50$ & $10-40$ & $8-20$ & $4-5$ & $68-100$ & $20-50$ & & & $10-23$ \\
\hline Nine & $8-10$ & 5-10 & $4-8$ & $3-4$ & $68-100$ & $20-50$ & & & $10-23$ \\
\hline Ten & $5-8$ & $4-5$ & $3-4$ & $2-3$ & $68-100$ & $20-50$ & & & $10-23$ \\
\hline
\end{tabular}

Table A I.

Benchmark land prices table for Beijing City in 1993
Notes:

Exchange rate between US\$ and Chinese Yuan before the introduction of the reform in exchange rate system on 1 January 1994 was 1 US\$: 10 Yuan

Source: Beijing City Government Document No. 34, 1993 
The benchmark price for particular use (1) for a particular land grade is obtained by the following formula:

BMP/sq.m $=(1) \times$ plot ratio factor $+[(2)+(3)] \times$ plot ratio $+(4) \times$ adjustment factor $+(5)$

or (6)

Real estate

development in

China

Where:

- the adjustment factor is 2 when the sitting tenant to be resettled is a state enterprise, and 4 when it is a commercial or special land user;

- the plot ratio is the ratio of gross floor area to site area;

- the plot ratio factor is obtained from Table All.

\begin{tabular}{ccccccccccc}
\hline Plot ratio factor & 1 or less & 2 & 3 & 4 & 5 & 6 & 7 & 8 & 9 & 10 \\
\hline 1 & 1.91 & 2.74 & 3.5 & 4.2 & 4.9 & 5.6 & 6.3 & 7 & 7.7
\end{tabular}

Table AlI.

Determination of plot ratio factor

\begin{tabular}{lcr}
\hline Items & $\begin{array}{r}\text { Unit price } \\
\text { (US\$/sq.m) }\end{array}$ & $\begin{array}{r}\text { Percentag } \\
\text { total cost }\end{array}$ \\
\hline Civil engineering & 83.6 & 70.75 \\
M echanical and el ectrical engineering: & 13.6 & 11.54 \\
HAVC & 8.2 & 6.96 \\
Sanitation facilities & 10.6 & 8.96 \\
Telephone lines & 0.9 & 0.80 \\
Public antenna & 1.2 & 1.00 \\
Total & 118.0 & 100.00
\end{tabular}

Source: Lin (1994)

Table A III.

Construction cost breakdown for typical local residential housing in Beijing

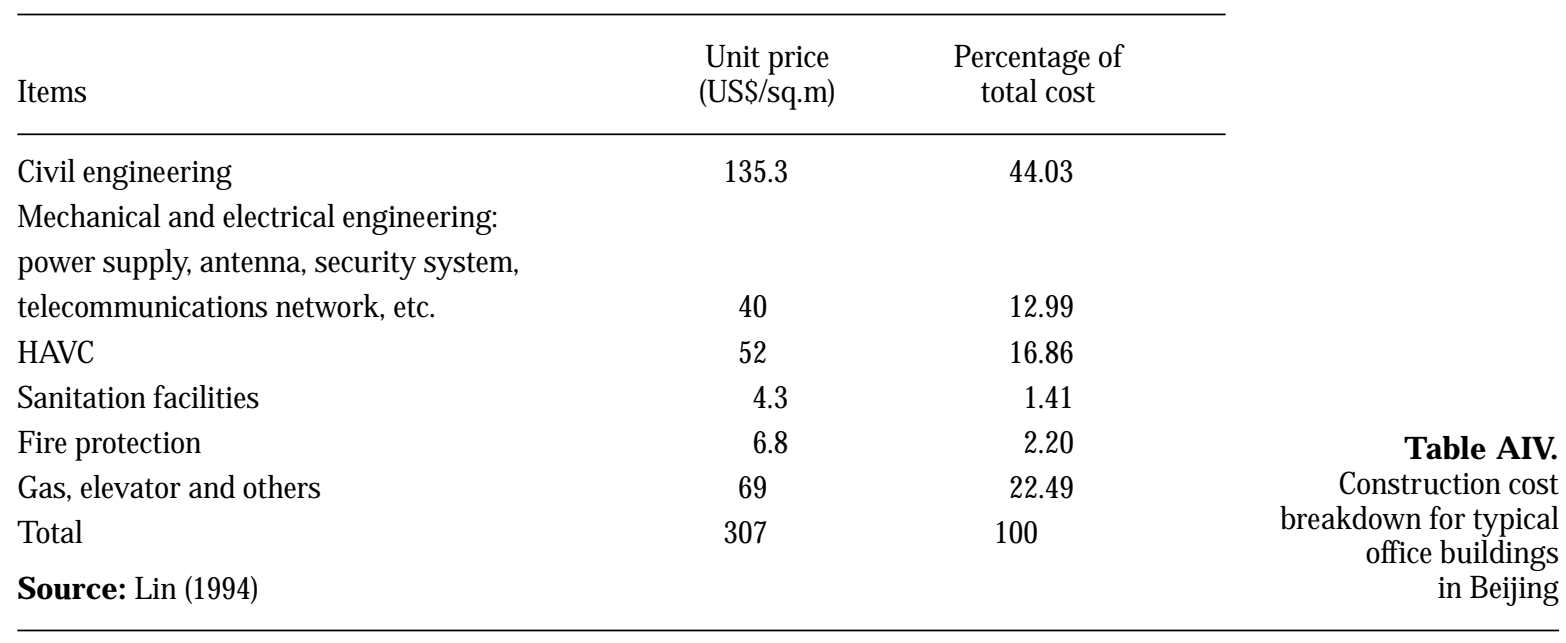

